\author{
MICHAŁ BRODECKI \\ Uniwersytet w Białymstoku \\ michal.broda8@wp.pl
}

\title{
Urlop bezpłatny a prawo do zasiłku dla bezrobotnych
}

Streszczenie. Artykuł porusza kwestie związane z zaliczaniem urlopów bezpłatnych do okresu uprawniającego do nabycia prawa do zasiłku dla bezrobotnych. Pomimo tego, iż na gruncie ustawy o promocji zatrudnienia i instytucjach rynku pracy istnieje szereg wątpliwości interpretacyjnych związanych z zaliczaniem urlopów bezpłatnych do stażu pracy warunkującego nabycie prawa do zasiłku dla bezrobotnych, temat ten nie jest poruszany $\mathrm{w}$ doktrynie często, co skutkuje rozbieżnościami $\mathrm{w}$ praktycznym stosowaniu przepisów. Opracowanie ma na celu rozwiązanie tych wątpliwości, a także zawiera wnioski de lege ferenda.

Słowa kluczowe: zasiłek dla bezrobotnych; urlop bezpłatny; urlop bezpłatny a zasiłek; urlop z art. 174 k.p.; wliczanie urlopu bezpłatnego do stażu pracy.

Summary. This article is about influence a unpaid furlogh on acquisition of the right to unemployment benefit. There are many ambiguities in the law regarding the granting of furlogh for seniority, which is dependent on the acquisition of the entitlement to unemployment benefit. In spite of this, this topic is not dealt with in doctrine. This results in discrepancies in the practical application of the law. This articler is intended to address the concerns and conclusions of the de lege ferenda.

Key words: unemployment benefit; unpaid furloghe; unpaid furlogh and benefit; furlogh from art. 174 k.p.; Include unpaid furlogh to seniority.

Bezrobocie jest zjawiskiem bardzo powszechnym we współczesnych społeczeństwach, niezależnie od stopnia ich rozwoju. Zgodnie z danymi Głównego Urzędu Statystycznego stopa bezrobocia w Polsce wynosi 8,5\% ${ }^{1}$. W celu zapobiegania zjawisku bezrobocia oraz ograniczania jego skutków tworzone są różnego rodzaju instrumenty. Najpowszechniejszym z nich jest obecnie zasiłek dla bezrobotnych. W doktrynie definiuje się go jako świadczenie o charakterze publicznoprawnym, finansowane ze specjalnego funduszu celowego Funduszu Pracy ${ }^{2}$. Zasiłek dla bezrobotnych uregulowany został w rozdziale 15 ustawy z dnia 20 kwietnia 2004 r. o promocji zatrudnienia i instytucjach rynku pracy ${ }^{3}$ (zwanej w dalszej części opracowania ustawą o promocji zatrudnienia), zatytułowanym ,świadczenia dla bezrobotnych”. Pomijając kwestie związane ze wskazaniem charakteru prawnego

Dane z lutego 2017 r., http://stat.gov.pl/podstawowe-dane/ [dostęp: 21.04 .2017 r.].

W. Sanetra, Zatrudnienie i bezrobocie. Przepisy i komentarz, Warszawa 1993, s. 26.

Dz. U. Nr 99, poz. 1001 ze zm. 
wzmiankowanego świadczenia, który nie jest jednoznaczny, a co nie jest przedmiotem niniejszego opracowania, wskazać należy, iż zgodnie $\mathrm{z}$ poglądami wyrażonymi w orzecznictwie sądów administracyjnych, ,przyznanie i wypłata zasiłku jest ostatecznym środkiem pomocy udzielanym bezrobotnym dopiero wówczas, gdy nie jest możliwe zastosowanie tzw. aktywnych form przeciwdziałania bezrobociu, a przede wszystkim nie ma dla danej osoby propozycji odpowiedniego zatrudnienia ${ }^{4}$.

Nie wchodząc w szczegóły dotyczące przesłanek nabycia prawa do zasiłku dla bezrobotnych, które obszernie uregulowane zostały w art. 71 ustawy o promocji zatrudnienia, uogólniając, należy stwierdzić, że zasiłek dla bezrobotnych przysługuje bezrobotnemu za każdy dzień kalendarzowy od dnia zarejestrowania się we właściwym powiatowym urzędzie pracy, gdy nie ma dla niego propozycji odpowiedniej pracy, propozycji stażu, przygotowania zawodowego dorosłych, szkolenia, prac interwencyjnych lub robót publicznych oraz posiada on w okresie 18 miesięcy bezpośrednio poprzedzających dzień zarejestrowania, łącznie przez okres co najmniej 365 dni tzw. okres aktywności zawodowej, podczas którego była odprowadzana składka na Fundusz Pracy, co do zasady od kwoty przynajmniej minimalnego wynagrodzenia za pracę określonego odrębnymi przepisami prawa.

$\mathrm{W}$ art. 71 ust. 1 pkt 2 lit. a) ustawy o promocji zatrudnienia wskazano, iż do okresu zatrudnienia warunkującego nabycie prawa do zasiłku dla bezrobotnych nie wlicza się okresów urlopów bezpłatnych trwających łącznie dłużej niż 30 dni. A contratio należy uznać, iż do okresu aktywności zawodowej, na potrzeby nabycia prawa do zasiłku wliczają się oczywiście urlopy bezpłatne trwające poniżej 30 dni. Dodatkowo wskazać należy, iż z powyższego wynika, że zaliczeniu do okresu uprawniającego do nabycia prawa do zasiłku dla bezrobotnych podlegały będą okresy urlopu bezpłatnego poniżej $30 \mathrm{dni}$ i to niezależnie, czy był on udzielony jednorazowo, czy też wielokrotnie ${ }^{5}$. Ustawodawca nie definiuje jednak szczegółowo, o jakie urlopy bezpłatne chodzi. Mając na uwadze powyższe, na gruncie przepisów ustawy o promocji zatrudnienia dochodzi do szeregu wątpliwości interpretacyjnych, czy powyższe stwierdzenie ustawodawcy dotyczy wszelkich urlopów bezpłatnych, czy tylko niektórych $\mathrm{z}$ nich. Rozważania na ten temat będą przedmiotem niniejszego opracowania.

4 Wyrok Wojewódzkiego Sądu Administracyjnego w Warszawie z dnia 14 czerwca 2006 r., II SA/Wa 463/06, LEX nr 221873.

5 Z. Góral, Komentarz do art. 71 ustawy o promocji zatrudnienia i instytucjach rynku pracy, w: Ustawa o promocji zatrudnienia i instytucjach rynku pracy. Praktyczny komentarz, red. Z. Góral, Warszawa 2012, s. 450 . 
Urlop bezpłatny rozumiany jest jako przerwa w świadczeniu przez pracownika pracy, w czasie której ulegają zawieszeniu wzajemne prawa i obowiązku stron stosunku pracy. W okresie urlopu bezpłatnego pracownik zostaje czasowo zwolniony $\mathrm{z}$ obowiązku świadczenia pracy a pracodawca z obowiązku wypłaty wynagrodzenia ${ }^{6}$. Wyróżnić można trzy rodzaje urlopów bezpłatnych:

- urlop bezpłatny udzielany na wniosek pracownika (art. 174 k.p.);

- urlop bezpłatny udzielany z inicjatywy pracodawcy, za pisemną zgodą pracownika, w celu wykonywania pracy u innego pracodawcy (art. $174^{1}$ k.p.),;

- tzw. urlopy funkcyjne unormowane poza Kodeksem pracy (m.in. urlop bezpłatny na okres pełnienia z wyboru funkcji związkowej poza zakładem pracy, urlop dla nauczyciela, urlop na okres sprawowania mandatu posła lub senatora, urlop dla radnego, urlop przyznawany urzędnikom służby cywilnej, urlop udzielany wybranemu na członka Krajowej Rady Radiofonii i Telewizji, urlop udzielany pracownikowi na czas wykonywania służby za granicą w przedstawicielstwie dyplomatycznym lub urzędzie konsularnym, urlop na czas pełnienia funkcji członka zarządu komisarycznego banku, czy urlop w celu odbycia ćwiczeń wojskowych).

Przez przedstawicieli doktryny został sformułowany pogląd, iż ustawodawca w treści art. 71 ust. 2 pkt 1 ustawy o promocji zatrudnienia miał na myśli urlopy udzielane na podstawie art. 174 k.p., na wniosek pracownika ${ }^{7}$. Zgodnie z art. $174 \S 2$ k.p. okresu urlopu bezpłatnego nie wlicza się do okresu pracy, od którego zależą uprawnienia pracownicze. Pogląd ten, moim zdaniem, jest jednak właściwy tylko w części. Wskazać należy w tym miejscu, iż z przepisu art. 174 k.p. nie wynika jednoznacznie, iż okresu tego typu urlopów nie należy zaliczać na poczet uprawnień zasiłkowych, ponieważ zasiłek dla bezrobotnych nie jest uprawnieniem pracowniczym, a wręcz przeciwnie, świadczeniem na wypadek bezrobocia. $\mathrm{Z}$ uwagi jednak na fakt, iż warunkiem uzyskania prawa do zasiłku dla bezrobotnych jest osiąganie wynagrodzenia w wysokości co najmniej minimalnego wynagrodzenia za pracę, którego w czasie urlopu bezpłatnego pracownik nie uzyskuje, a także odprowadzanie składki na Fundusz Pracy, która również nie jest odprowadzana w czasie urlopu bezpłatnego pracownika, należy wskazać, że urlop ten oddziałuje negatywnie na uprawnienia pracownika do zasiłku dla bezrobotnych. Ograniczenie jednak przez doktrynę urlopów bezpłatnych,

A. Martuszkiewicz, K. Piecyk, Urlopy pracownicze i inne zwolnienia od pracy, Warszawa 2010, s. 141.

Z. Góral, Komentarz do art. 71 ustawy o promocji zatrudnienia i instytucjach rynku pracy, w: Ustawa ..., red. Z. Góral, s. 450. 
których okresu nie wlicza się do uprawnień zasiłkowych, jedynie do urlopów określonych w art. 174 k.p., jest moim zdaniem niewłaściwe, albowiem ustawodawca w treści art. 71 ust. 1 pkt 2 lit. a) ustawy o promocji zatrudnienia wskazał, że chodzi tu o urlopy bezpłatne, a więc o wszelkie urlopy bezpłatne, zaś ewentualnych wyłączeń możemy dopatrywać się w przepisach ustawy o promocji zatrudnienia, o czym będzie mowa w dalszej części niniejszego opracowania. Gdyby bowiem ustawodawca chciał zróżnicować nabycie uprawnień do zasiłku dla bezrobotnych, wskazałby to wprost w treści ustawy.

Wskazać należy jednak na sytuację, w której pracownik, w trakcie trwania urlopu bezpłatnego u jednego pracodawcy, podejmie pracę $\mathrm{u}$ innego pracodawcy. Często bowiem podjęcie takiego zatrudnienia jest celem urlopu bezpłatnego ${ }^{8}$. Pracownicy bardzo często biorą urlop bezpłatny, gdy chcą zmienić pracę, ale przed rezygnacją $\mathrm{z}$ dotychczasowego zatrudnienia chcą sprawdzić warunki u potencjalnego, nowego pracodawcy. W tej sytuacji oczywistym jest, że okres zatrudnienia u innego pracodawcy $\mathrm{w}$ trakcie trwania urlopu bezpłatnego nie może skutkować niewliczaniem tego okresu do uprawnień zasiłkowych, co potwierdza jednolita w tym zakresie linia orzecznicza sądownictwa administracyjnego „okoliczność równoczesnego przebywania na urlopie bezpłatnym w jednym miejscu zatrudnienia nie wyklucza uwzględnienia tego okresu przy ustaleniu uprawnień do zasiłku, jeśli spełnione zostały inne przesłanki ustawowe do jego zaliczenia ${ }^{9}$ ".

Przechodząc do wspomnianych przeze mnie wcześniej wyłączeń w zakresie wliczania do okresu uprawniającego do zasiłku dla bezrobotnych urlopów bezpłatnych, należy wskazać, że na gruncie ustawy o promocji zatrudnienia istnieją jedynie cztery takie wyłączenia:

- zgodnie $\mathrm{z}$ art. 71 ust. 2 pkt 2 ustawy o promocji zatrudnienia, do 365 dni warunkujących nabycie uprawnień do zasiłku dla bezrobotnych zalicza się również okresy urlopu wychowawczego udzielonego na podstawie odrębnych przepisów. $\mathrm{W}$ tym wypadku ustawodawca wskazał również w treści art. 104 ust. 1 pkt 3 lit. g) wspomnianej ustawy, iż osoby przebywające na urlopach wychowawczych zwolnione są z opłacania składek na Fundusz Pracy, pomimo tego, że podlegają w tym czasie obowiązkowym ubezpieczeniom społecznym. Zasady udzielania wzmiankowanego urlopu określone są w art. 186 i n. k.p.;

- zgodnie z art. 72 ust. 4 ustawy o promocji zatrudnienia, do okresu uprawniającego do zasiłku, od którego zależy wysokość i okres pobierania zasiłku, zalicza się również

$8 \quad$ T. Romer, Kodeks pracy. Komentarz, Warszawa 2012, s. 945.

9 Wyrok Wojewódzkiego Sądu Administracyjnego w Krakowie z dnia 25 października 2011 r., III SA/Kr 1220/2010, LexPolonica nr 3090522. 
okresy urlopu bezpłatnego udzielonego na podstawie przepisów w sprawie bezpłatnych urlopów dla matek pracujących, opiekujących się małymi dziećmi, innych udzielonych w tym celu urlopów bezpłatnych. W niniejszej regulacji chodzi o urlopy bezpłatne dla matek pracujących, opiekujących się małymi dziećmi, wprowadzone uchwałą nr 158 Rady Ministrów z dnia 24 maja 1968 r. w sprawie bezpłatnych urlopów dla matek pracujących, opiekujących się dziećmi ${ }^{10}$, a także inne, udzielane w tym celu urlopy bezpłatne oraz przerwy w zatrudnieniu, które spowodowane są opieką nad dziećmi w określonych przez prawodawcę limitach czasowych, które przypadały przed dniem 8 czerwca 1968 r. $^{11}$;

- zgodnie z art. 89 ust. 2 ustawy o promocji zatrudnienia, okres urlopu bezpłatnego udzielonego pracownikowi na okres skierowania do pracy za granicą na podstawie rozporządzenia Rady Ministrów z dnia 27 grudnia 1974 r. w sprawie niektórych praw i obowiązków pracowników skierowanych do pracy za granicą w celu realizacji budownictwa eksportowego i usług związanych z eksportem ${ }^{12}$, a także przypadający bezpośrednio po zakończeniu tego urlopu okres niezdolności do pracy z powodu choroby lub odosobnienia w związku z chorobą zakaźną - wlicza się do okresu pracy, od którego zależą uprawnienia pracownicze, jeżeli pracownik podjął zatrudnienie $\mathrm{u}$ macierzystego pracodawcy w terminie przewidzianym w tym rozporządzeniu;

- zgodnie z art. 89 ust. 3 ustawy o promocji zatrudnienia, okres zatrudnienia za granicą pracownika, który nie pozostawał w stosunku pracy przed skierowaniem do pracy za granicą na podstawie rozporządzenia, o którym mowa w ust. 2, jest traktowany jak okres zatrudnienia w Rzeczypospolitej Polskiej w zakresie uprawnień pracowniczych. Dotyczy to także pracownika, któremu udzielono urlopu bezpłatnego na okres skierowania do pracy za granicą, a który nie podjął pracy u macierzystego pracodawcy po zakończeniu pracy za granicą lub podjął pracę u macierzystego pracodawcy, lecz po upływie terminu przewidzianego w rozporządzeniu, o którym mowa w punkcie poprzednim.

Wskazać należy w tym miejscu, iż dwa ostatnie wyłączenia należy interpretować łącznie z ust. 1 art. 89 ustawy o promocji zatrudnienia, zgodnie z którym chodzi tu o okresy zatrudnienia obywateli polskich w byłej Niemieckiej Republice Demokratycznej i byłej Czechosłowackiej Republice Socjalistycznej, zaś rozporządzenie, o którym w nich mowa,

\footnotetext{
10 M. P. Nr 24, poz. 154 ze zm.

11 Z. Góral, Komentarz do art. 71 ustawy o promocji zatrudnienia i instytucjach rynku pracy, w: Ustawa..., s. 466.

12 Dz. U. z 1990 r. Nr 44, poz. 259, z 1991 r. Nr 78, poz. 346 oraz z 1993 r. Nr 99, poz. 452
} 
utraciło moc z dniem 3 czerwca 1998 r., na mocy ustawy z dnia 2 lutego 1996 r. o zmianie ustawy - Kodeks pracy oraz o zmianie niektórych innych ustaw ${ }^{13}$.

Na tle dwóch ostatnich wyłączeń w zakresie zaliczania do okresu uprawniającego do zasiłku urlopów bezpłatnych, rodzi się pytanie, w jaki sposób należy traktować urlop udzielany na podstawie art. $174^{1}$ k.p., głównie z uwagi na treść $\S 2$ wskazanego przepisu, a więc wliczanie się omawianego urlopu do okresu pracy, od którego zależą uprawnienia pracownicze, w szczególności w kontekście opinii wyrażonej przez judykaturę, zgodnie $\mathrm{z}$ którą dopiero podjęcie pracy u dotychczasowego pracodawcy umożliwia zaliczenie okresu tego urlopu do okresu pracy, od którego zależą uprawnienia pracownicze ${ }^{14}$. Urlop udzielany na tej podstawie jest wszak analogiczny do określonego we wspomnianym, nieobowiązującym już rozporządzeniu, z tą różnicą, że praca pracownika skierowanego do innego pracodawcy niekoniecznie musi odbywać się za granicą. Wydawałoby się, że urlop ten nie będzie wpływał negatywnie na okres aktywności zawodowej wymagany do uzyskania prawa do zasiłku dla bezrobotnych. Moim zdaniem jednak, powyższe uzależnione będzie od warunków pracy i płacy u pracodawcy, któremu pracownik został „przekazany”, albowiem jak podnosi się w doktrynie, ,wynikające z zawartej umowy o pracę warunki zatrudnienia pracownika u nowego pracodawcy nie muszą odpowiadać tym, które stanowią treść zawieszonego $\mathrm{w}$ danym czasie stosunku pracy u pracodawcy macierzystego ${ }^{15}$. Oznacza to, że u nowego pracodawcy, pracownik nie musi wcale pracować $\mathrm{w}$ takim samym wymiarze czasu pracy, jak u pracodawcy macierzystego, ani osiągać dochodu w wysokości minimalnego wynagrodzenia za pracę, od którego istnieje obowiązek odprowadzania składek na Fundusz Pracy. Z uwagi na powyższe, np. rozwiązanie przez pracownika umowy o pracę w czasie jej wykonywania u pracodawcy, któremu został „przekazany”, w kontekście wspomnianego powyżej orzeczenia Sądu Najwyższego, skutkowałoby utratą uprawnień pracowniczych, a tym samym prawa do zasiłku dla bezrobotnych. Mając również na uwadze ratio legis instytucji $\mathrm{z}$ art. $174^{1}$ k.p., należy stwierdzić, że służy on uelastycznieniu gospodarowania zasobami pracy, poprzez „przekazywanie” pracowników pomiędzy pracodawcami, gdy jeden z nich przejściowo ma kłopoty z zapewnieniem pracy wszystkim pracownikom, drugiemu zaś niezbędne jest czasowe zwiększenie stanu zatrudnienia ${ }^{16}$. $\mathrm{Z}$ uwagi na powyższe, pracodawca macierzysty zostaje zwolniony na czas trwania urlopu

13 Dz. U. Nr 24, poz. 110 ze zm.

14 Wyrok Sądu Najwyższego z dnia 9 stycznia 2009 r., I PK 118/08, LEX nr 736703.

15 A. Kosut, Komentarz do art. $174^{1}$ k.p., w: Kodeks pracy. Komentarz, red. K.W. Baran, Warszawa 2012 , s. 967.

16 A. Kosut, Komentarz do ..., s. 966. 
bezpłatnego pracownika udzielonego $\mathrm{w}$ tym trybie $\mathrm{z}$ ponoszenia wszelkich ciężarów publicznoprawnych związanych $\mathrm{z}$ zatrudnieniem pracownika, $\mathrm{w}$ tym składek na ubezpieczenia społeczne i Fundusz Pracy. Wskazać należy także, iż gdyby ustawodawca miał na celu rozszerzenie katalogu urlopów bezpłatnych, których okres zalicza się do uprawnień zasiłkowych, wskazałby je wprost w treści ustawy, nie zostawiając w tym zakresie luki. Zaznaczyć także należy, iż zgodnie z poglądami wyrażonymi w orzecznictwie sądownictwa administracyjnego, katalog przesłanek wymienionych w art. 71 ustawy o promocji zatrudnienia posiada charakter zamknięty ${ }^{17}$, oraz pozbawiony jest cech uznaniowości ${ }^{18}$, zaś warunkiem uzyskania prawa do zasiłku dla bezrobotnych jest kumulatywne spełnienie dwóch przesłanek z art. 71 ust. 1 pkt 1 i 2 ustawy o promocji zatrudnienia ${ }^{19}$, co jedynie potwierdza słuszność tego twierdzenia.

Nadmienić należy także, iż zgodnie z opinią judykatury ,przepis art. 71 ust. 1 pkt 2 lit. a ustawy z 20 kwietnia 2004 r. o promocji zatrudnienia stanowi wyraźnie, że okresów urlopów bezpłatnych trwających łącznie dłużej niż 30 dni nie uwzględnia się w okresie 18 miesięcy poprzedzających dzień zarejestrowania. Jeżeli takie jest znaczenie przepisu mającego zastosowanie w niniejszej sprawie, to od czasu przypadającego na okres „obrachunkowy”, w którym strona rzeczywiście pozostawała w zatrudnieniu i osiągała wynagrodzenie w kwocie co najmniej minimalnego wynagrodzenia za pracę nie można odejmować czasokresu przebywania na urlopie bezpłatnym, który wykraczał poza okres „obrachunkowy” brany pod uwagę przy ustalaniu prawa do zasiłku dla bezrobotnych ${ }^{20}$,

Kwestią sporną pozostawało przez długi czas skorzystanie przez pracownika uprawnionego do urlopu wychowawczego z obniżonego wymiaru czasu pracy, na podstawie art. $186^{7} \S 1$ k.p., ponieważ często wiązało się to $\mathrm{z}$ faktem nieosiągania przez pracownika w tym okresie co najmniej minimalnego wynagrodzenia za pracę, co warunkuje uzyskanie prawa do zasiłku. W jednym ze swoich wyroków Wojewódzki Sąd Administracyjny w Rzeszowie stwierdził jednak, iż skorzystanie przez pracownika uprawnionego do urlopu wychowawczego z obniżonego wymiaru czasu pracy na podstawie art. $186^{7}$ k.p. ma ten skutek, że okres takiego zatrudnienia podlega wliczeniu do 365 dni przypadających w okresie

17 Wyrok Wojewódzkiego Sądu Administracyjnego w Gliwicach z dnia 14 października 2010 r., IV SA/Gl 269/2010, LexPolonica nr 2519125.

18 Wyrok Wojewódzkiego Sądu Administracyjnego we Wrocławiu z dnia 20 sierpnia 2009 r., IV SA/Wr 196/2009, LexPolonica nr 2503023.

19 Wyrok Wojewódzkiego Sądu Administracyjnego w Gliwicach $\mathrm{z}$ dnia 9 grudnia 2008 r., IV SA/G1 541/2008, LexPolonica nr 2062762.

20 Wyrok Naczelnego Sądu Administracyjnego z dnia 27 czerwca 2012 r., I OSK 152/2012, LexPolonica nr 3960049. 
18 miesięcy poprzedzających dzień zarejestrowania również w sytuacji, gdy w okresie obniżonego wymiaru czasu pracy pracownik nie osiągał co najmniej minimalnego wynagrodzenia za pracę ${ }^{21}$. Powyższe twierdzenie Sąd wywiódł z konieczności respektowania wartości konstytucyjnych, w tym ochrony rodzicielstwa zawartej w art. 18 Konstytucji Rzeczpospolitej Polskiej oraz gwarancji w zakresie prawa do zabezpieczenia społecznego w przypadku pozostawania bez pracy (art. 67 ust. 2 Konstytucji). Zdaniem Sądu, konsekwencją prokonstytucyjnej wykładni powołanych wyżej przepisów jest następujące uogólnienie: skorzystanie przez uprawnionego do urlopu wychowawczego pracownika z obniżonego wymiaru czasu pracy na podstawie art. $186^{7}$ k.p. ma ten skutek, że okres takiego zatrudnienia podlega wliczeniu do 365 dni przypadających w okresie 18 miesięcy poprzedzających dzień zarejestrowania również w sytuacji, gdy w okresie obniżonego wymiaru czasu pracy pracownik nie osiągał co najmniej minimalnego wynagrodzenia za pracę. Skład orzekający zauważył również, że hipotetycznie, gdyby pracownica wybrała urlop wychowawczy, to okres tego urlopu podlegałby wliczeniu do $365 \mathrm{dni}$, o jakich mowa w art. 71 ust. 1 pkt 2 lit. a) ustawy o promocji zatrudnienia. Gdyby natomiast nie skorzystała $\mathrm{z}$ alternatywnego uprawnienia do urlopu wychowawczego i pozostała w zatrudnieniu w pełnym wymiarze czasu pracy, to musiałaby osiągać kwoty minimalnego wynagrodzenia za pracę. $\mathrm{W}$ obu więc teoretycznych wariantach, $\mathrm{z}$ chwilą rejestracji $\mathrm{w}$ organie zatrudnienia, nabyłaby prawo do świadczenia dla bezrobotnych. Wobec tego skorzystanie z alternatywnego dla urlopu wychowawczego uprawnienia, jakim jest obniżenie wymiaru czasu pracy na podstawie art. $186^{7}$ k.p., ze skutkiem w postaci nieuwzględnienia tego okresu do 365 dni, godziłoby w zasadę sprawiedliwości społecznej, wyrażoną w art. 2 Konstytucji ${ }^{22}$. Z powyższą wykładnią nie sposób się nie zgodzić, z uwagi na co wzmiankowane orzeczenie należy uznać za słuszne, spójne i zgodne z zasadami logiki.

Konkludując, należy stwierdzić, że do okresu uprawniającego do nabycia prawa do zasiłku dla bezrobotnych nie zalicza się urlopów bezpłatnych trwających powyżej 30 dni (bez przerwy), za wyjątkiem urlopów wyłączonych spod tej sankcji przez ustawodawcę na gruncie ustawy o promocji zatrudnienia $i$ instytucjach rynku pracy, tj. urlopu wychowawczego, urlopu bezpłatnego udzielonego na podstawie przepisów w sprawie bezpłatnych urlopów dla matek pracujących, opiekujących się małymi dziećmi, innych udzielonych w tym celu urlopów bezpłatnych, a także urlopów określonych w art. 89

\footnotetext{
21 Wyrok Wojewódzkiego Sądu Administracyjnego w Rzeszowie $\quad \mathrm{z}$ dnia 13 listopada 2013 r., II SA/Rz 1027/13, ONSA i WSA 2014, nr 6, poz. 109, str. 213.

22 Wyrok Wojewódzkiego Sądu Administracyjnego w Rzeszowie z dnia 13 listopada 2013 r.
} 
ust. 2 i 3 ustawy o promocji zatrudnienia. Wskazać należy również, iż w zakresie interpretacji niniejszego zagadnienia, nie należy stosować wykładni rozszerzającej ani wychodzić poza tekst ustawy, ponieważ ustawodawca, wskazując w jej treści urlopy bezpłatne, których okresy zaliczają się do uprawnień zasiłkowych, posłużył się katalogiem enumeratywnym, zaś jeśli jego celem byłoby rozszerzenie wyłączeń $\mathrm{w}$ zakresie stosowania przesłanki z art. 71 ust. 2 pkt a) ustawy o promocji zatrudnienia, takie $\mathrm{z}$ pewnością znalazłyby się $\mathrm{w}$ treści ustawy. Niezależnie jednak od powyższego, celem zniwelowania wątpliwości w zakresie zaliczania okresów urlopów bezpłatnych na potrzeby uprawnień do zasiłku dla bezrobotnych, należałoby przeredagować tekst ustawy w ten sposób, ażeby była ona bardziej precyzyjna i klarowna, a także nie stwarzała tylu wątpliwości interpretacyjnych, nie tylko w tej kwestii. Ustawa bowiem, choć obszerna i zawiera wiele istotnych treści, nie jest jednak spójna. Zasadnym byłoby w tym wypadku przeredagowanie art. 71 ust. 2 pkt a) w następujący sposób: był zatrudniony i osiągał wynagrodzenie w kwocie co najmniej minimalnego wynagrodzenia za pracę, od którego istnieje obowiązek opłacania składki na Fundusz Pracy, z zastrzeżeniem art. 104a-105; w okresie tym nie uwzględnia się okresów urlopów bezpłatnych trwających łącznie dłużej niż 30 dni, za wyjątkiem urlopów określonych w art. 71 ust. 2 pkt 2, art. 72 ust. 4, art. 89 ust 2 i 3. niniejszej ustawy. Redakcja taka z pewnością rozwiałaby wszelkie wątpliwości w tej kwestii i ułatwiłaby stosowanie przepisów ustawy.

\section{Bibliografia:}

\section{Literatura}

Góral Z., Ustawa o promocji zatrudnienia $i$ instytucjach rynku pracy. Praktyczny komentarz, Warszawa 2012

Kosut A., Komentarz do art. $174^{1}$ k.p., w: Kodeks pracy. Komentarz, red. K.W. Baran, Warszawa 2012 Martuszkiewicz A., Piecyk K., Urlopy pracownicze i inne zwolnienia od pracy, Warszawa 2010

Romer T., Kodeks pracy. Komentarz, Warszawa 2012

Sanetra W., Zatrudnienie i bezrobocie. Przepisy i komentarz, Warszawa 1993

\section{Orzecznictwo}

Wyrok Wojewódzkiego Sądu Administracyjnego w Warszawie z dnia 14 czerwca 2006 r., II SA/Wa 463/06, LEX nr 221873

Wyrok Wojewódzkiego Sądu Administracyjnego w Gliwicach z dnia 9 grudnia 2008 r., IV SA/Gl 541/2008, LexPolonica nr 2062762

Wyrok Sądu Najwyższego z dnia 9 stycznia 2009 r., I PK 118/08, LEX nr 736703

Wyrok Wojewódzkiego Sądu Administracyjnego we Wrocławiu z dnia 20 sierpnia 2009 r., IV SA/Wr 196/2009, LexPolonica nr 2503023

Wyrok Wojewódzkiego Sądu Administracyjnego w Gliwicach z dnia 14 października 2010 r., IV SA/G1 269/2010, LexPolonica nr 2519125

Wyrok Wojewódzkiego Sądu Administracyjnego w Krakowie z dnia 25 października 2011 r., III SA/Kr 1220/2010, LexPolonica nr 3090522 
Wyrok Naczelnego Sądu Administracyjnego z dnia 27 czerwca 2012 r., I OSK 152/2012, LexPolonica nr 3960049

Wyrok Wojewódzkiego Sądu Administracyjnego w Rzeszowie z dnia 13 listopada 2013 r., II SA/Rz 1027/13, ONSA i WSA 2014, nr 6, poz. 109

\section{Źródla internetowe}

http://stat.gov.pl/podstawowe-dane/ [dostęp: 21.04.2017 r.]. 